\title{
Interdependence of Ratios in Banking Stability Pentagon
}

\author{
Katarzyna Kubiszewska*
}

The banking sector is one of the key sectors in every economy, therefore, the issue of stability is one of the main interests not only of researchers but also policy-makers. The stability of the banking sector is especially important during a process of transformation. The aim of this article is to present a new tool for estimating the stability of the banking sector as a whole.

Although the tool can be used to estimate the level of stability for all countries, the relationships between various variables and interdependence of the ratios used in the tool will differ between the countries surveyed, as tested in the article.

The study is based on selected countries from two regions: the Western Balkans and the Baltic Sea states that are either in the process of transformation or have just completed that. Due to the choice of the banking sectors under study, it was possible to perform a comparative analysis between countries that have already undergone the transformation process and those that are currently in the transformation process. The survey is based on quarterly data for the period Q1, 2010-Q1, 2016. The data has been sourced from the International Monetary Fund.

Keywords: transformation, banking sector, profitability, the Western Balkan region.

Submitted: 12.10 .18 | Accepted: 14.12.18

\section{Współzależność wskaźników w Pięciokącie Stabilności Bankowej}

Sektor bankowy jest jednym z kluczowych sektorów w każdej gospodarce, dlatego kwestia stabilności stanowi jeden z głównych tematów badawczych nie tylko naukowców, ale także decydentów. Stabilność sektora bankowego jest szczególnie ważna w procesie transformacji. Celem tego artykutu jest zaproponowanie narzędzia do szacowania stabilności sektora bankowego jako catości.

Chociaż narzędzie to można wykorzystać do oszacowania poziomu stabilności dla wszystkich krajów, relacje między różnymi zmiennymi $i$ wspótzależności wskaźników stosowanych $w$ narzędziu będa się różnić $w$ badanych krajach, co zbadano $w$ artykule.

Badanie opiera się na wybranych krajach $z$ dwóch regionów: Bałkanów Zachodnich i państw Morza Battyckiego, które sa w trakcie transformacji lub wtaśnie zakończyly ten proces. Ze względu na wybór badanych sektorów bankowych możliwe byto przeprowadzenie analizy porównawczej między krajami, które zakończyly już proces transformacji, a krajami, które

\footnotetext{
Katarzyna Kubiszewska - PhD, Gdańsk University of Technology, Faculty of Management and Economics.

Correspondence address: Faculty of Management and Economics, Gdańsk University of Technology, G. Narutowicza 11/12, 80-233 Gdańsk, e-mail: katarzyna.kubiszewska@zie.pg.gda.pl.
} 
sa obecnie $w$ trakcie transformacji. Badanie opiera sie na danych kwartalnych za okres I kw. 2010 r. - I kw. 2016 r. Dane pochodza z Międzynarodowego Funduszu Walutowego.

Słowa kluczowe: transformacja, sektor bankowy, zyskowność, Bałkany Zachodnie. Nadesłany: 12.10 .18 | Zaakceptowany do druku: 14.12.18

JEL: G20, G21

\section{Introduction}

The banking sector is one of the key sectors in every economy, therefore the issue of its stability is one of the main interests of not only researchers but also policymakers. The banking sector's stability is especially important if the sector is in the process of transformation. The aim of this article is to present a new tool for estimating the stability of the banking sector as a whole, based on financial ratios from the CAMELS system. The other objective of the paper is to evaluate the interdependence of these ratios. The study is based on selected countries from two regions: the Western Balkans and the Baltic Sea states. Due to the choice of banking sectors under study it was possible to perform a comparative analysis. The survey is based on quarterly data for the period Q1, 2010-Q1, 2016. The data has been sourced from the International Monetary Fund.

\section{The issue of banking stability in transition economies - a literature review}

It is not an easy task to define banking stability, or to measure it. On the one hand, it is well known that both measuring and assessing banking stability is one of the key issues for all participants in this market. On the other, neither literature nor practice are able to find one common tool with which to evaluate this market's situation. The reason for this is the lack of one common definition for the issue of banking stability, which indicates its complexity. The explanation for the term provided in the literature can be split into three groups. Firstly, banking stability is understood as an economic sector that is performing well and developing, and which accomplishes its aims and objectives. Secondly, banking stability is associated with an impact on other business sectors and a mutual interdependence. Also, banking stability is influenced by various policies that directly aim to manage other business sectors. Thirdly, banking stability can be understood as a lack of crisis, which creates the additional problem of providing a common definition for a banking crisis.

Banking system stability refers to the principal components of the system (institutions, markets, and infrastructure) that are jointly capable of absorbing adverse conditions. The banking system facilitates the smooth and efficient reallocation of financial resources from savers to investors, while risks are adequately priced and assessed in a reasonable manner and managed efficiently.

The influence of the banking sector on general economy and its impact on economic growth has already been studied and proved, both for developed economies and economies in transition. The issue remains of great importance in the case of economies in transition considering great complexity of the transformation process itself. Safe and sound banking sectors are essential, especially for of economies in transition where economic and banking stability is very weak. The steady process of banking reform involves these three areas: rebuilding the market's structures, introducing a new system of law, and creating completely new institutions to guarantee the correct functioning of the banking market. Unfortunately, banking crises experienced by economies in transition prove that their banking stability is badly insufficient. Therefore, measuring the level of stability in such countries should be a key issue.

Policymakers and academic researchers have focused on a number of quantitative measures in order to assess financial and banking stability. The literature provides examples of complex indices for situations in banking markets in various countries. A discrete financial stress index introduced by Bordo et al. (2001) included a number of factors: time series for business failures, banking conditions, the real interest rate, and an interest spread. A real, continuous 
indicator created by Puddu (2008) aggregates the banking sector's balance sheet variables. A financial stress index presented by Illing and Liu (2006) uses a varianceequal weighted to combine several financial market indicators into one single index. A continuous stress index, carried out by Hanschel and Monnin (2005), is based on various data, e.g. an equal-weighted market prices, as well as on data published in balance sheets.

A stability indicator was constructed for the Czech Republic by Geršl and Hermanek (2006) and it is based on weightings assigned to variables according to experts' judgment; while an aggregate financial stability indicator for Romania consists of subindices for financial development, financial vulnerability, financial soundness, and the world's economic climate (Albulescu, 2010). An aggregate financial stability index for Macao uses individual indicators grouped into the following categories: the financial soundness index, the financial vulnerability index, and the regional economic climate index (Cheang and Choy, 2011). A stability index for the entire banking system of Macedonia is based on quantitative indicators on the banks' performance according to the level of their influence on stability (Petrovska and Mihajlovska, 2013).

The set of financial soundness indicators (FSI) developed by the IMF (2006) is also used in constructing an index for the complex assessment of the banking sector. The studies use the FSI to create an early warning signal for potential banking crises. Such a study was launched by Čihák and Schaeck (2007) who found that the CAR and the NPL ratio provided signals indicating systemic banking problems and that the banks' ROE serves as an indicator for the timing of a crisis. This study was followed by Babihuga (2007) who tested FSIs against a number of macroeconomic indicators, concluding there was a strong relationship between FSIs and the business cycle, as well as with the inflation rate. Later and Sun (2011) developed it further, proving that leverage indicators are the most reliable indicator for forecasting a banking crisis. The study proves that capital adequacy and profitability show a significant negative contemporaneous relationship with the occurrence of banking crises with a focus on return of assets as a measurement of profitability, which is a significant leading indicator of crises (Navajas and Thegeya, 2013).

The literature analyses several aspects of banking sector reform and shows its consequences for different countries. Khan and Aftab (1994) reviewed the effect of denationalization and privatization aspects of financial reforms in Pakistan. They concluded that the denationalization of banks improved their performance in terms of growth of assets, recovery of loans, and the ratio of bad loans.

The impact of banking sector reforms on the fiscal and monetary stability of many transitional economies was assessed by Feldman and Wagnar (2002). They observed that the success of the reforms significantly contributed to fiscal and monetary stability. The relationship between reform and bank efficiency was also examined by Fu and Heffernan (2008). They studied the performance of the Chinese banking sector, and reviewed the reforms and their influences on profitability using the following indices: return on assets, return on equity, and net interest margin. They found a significant relationship between profitability and reform. Brownbridge and Gockel (2000) examined the necessity of banking sector reforms in Ghana during the 1980s and evaluated their impact. They concluded that the reforms have brought about improvements in the banking system and that banks are now more prudently managed and supervised.

\section{Interdependence of ratios}

In constructing the indices for banking stability, it is essential to learn about the mutual interdependence of the ratios used in this complex tool. The key elements of the banking sector are liquidity, profitability, credit activities, various aspects of risk, and capital adequacy.

The literature supports the view that there is an interdependency between liquidity risk and credit risk, however, the direction of this relationship is questioned. A very recent and still developing body of literature suggests the possibility that the relationship between liquidity and credit risk in banks might be negative (Wagner, 2007; Cai and Thakor, 2008; Gatev et al., 2009; Acharya et al., 2010; Acharya and Naqvi, 2012), while the opposing view proves a positive link (Bryant, 1980; Diamond and Dybvig, 1983; Samartín, 2003; Iyer and Puri, 2012). Unfortunately, based on these models, liquidity 
and credit risk should be positively related and therefore jointly contribute to bank instability (Imbierowicz, 2014).

Another important aspect is profitability and its determinants. The literature provides two groups of factors: external - not related to a bank, and internal - related to a bank. External factors include the status of economic development (Demirguc-Kunt and Huizinga, 1999; Dietrich and Wanzenried, 2008), market concentration, and banking sector reform (Košak and Cok, 2008; Claessens et al., 2001). Among the internal factors the following can be found:

1. the bank's size - positive and negative correlations (Pervan, Pervan and Guadagnino, 2010),

2. the bank's exposure to various types of risks - liquidity risk (Kosmidou, 2008), credit risk (Kundid, Skrabić and Ercegovac, 2011),

3. ownership (Athanasoglou, Brissimis and Delis, 2008),

4. liquidity, capital adequacy, and expenses management (Guru et al., 2002; Naceur and Goaied, 2008; Kosmidou 2008).
Capital adequacy is also a topic of various research projects. It was compared against profitability, liquidity, and risk, but the results are ambiguous. Both positive and negative correlations between capital adequacy and profitability were found, depending on the tool being used to measure it (Büyüksalvarc and Abdioğlu 2012; Ahmad et al., 2008; Kleff and Weber, 2008). Gropp and Heider (2007) found that profitable banks tend to have relatively greater equity (Abusharba et al., 2013).

\section{Research methods}

This analysis compares the situation of banking sectors in two groups of countries: the Western Balkans and the Baltic Sea states. The studies cover a period of five years between 2010 and 2016 and is based on a quarterly data.

The study was carried out in two stages. First, in order to evaluate the stability of the sector a new tool was introduced in the form of the banking stability pentagon (BSP); see Figure 1.

Figure 1. Banking stability pentagon

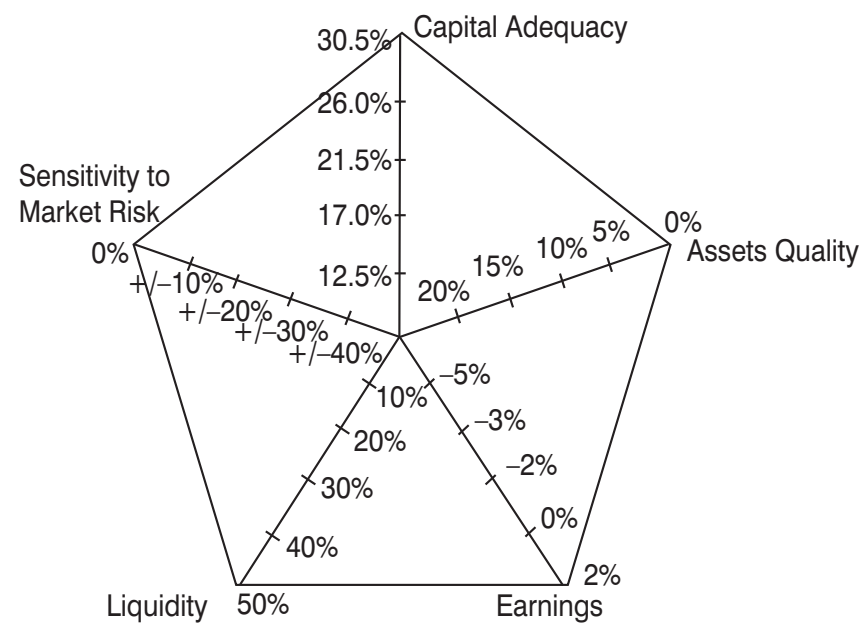

Source: own compilation.

The banking stability pentagon employs five ratios that originate from the CAMELS system. Each of the vertexes of the equilateral pentagon describe the current situation of one of the five areas of key importance in the stability of the banking market: capital, asset quality, earnings, liquidity, and sensitivity to market risk (Table 1). 


\begin{tabular}{|l|l|l|}
\hline & $\begin{array}{c}\text { Referring } \\
\text { perspective }\end{array}$ & \multicolumn{1}{c|}{ Ratio } \\
\hline C & $\begin{array}{l}\text { Capital } \\
\text { adequacy }\end{array}$ & $\begin{array}{l}\text { Capital adequacy indicates the capacity to absorb losses. It is based } \\
\text { on Tier 1 capital and Tier 2 capital. Tier 1 capital (equity) provides most } \\
\text { protection, while Tier 2 capital (e.g. Tier 1 + subordinated debt, unrealised } \\
\text { capital gains) gives less protection to creditors. Capital adequacy presents an } \\
\text { analysis of the capital structure using assets weighted for risk factors. } \\
\text { - Regulatory Capital to Risk-Weighted Assets }\end{array}$ \\
\hline A & $\begin{array}{l}\text { Asset } \\
\text { quality }\end{array}$ & $\begin{array}{l}\text { Asset quality reflects the probabilities of default or downgrade } \\
- \text { i.e. it is highly dependent on the asset credit rating. It is used to estimate } \\
\text { the possibility of recovering debts from borrowers. } \\
\text { - Non-performing Loans to Total Gross Loans }\end{array}$ \\
\hline E & Earnings & $\begin{array}{l}\text { Comparing profit in terms of value does not provide a relevant insight into } \\
\text { the banking sector, however, profitability can be measured and compared. } \\
\text { The Return On Assets ratio takes into account: } \\
\text { - the net profit of the sector } \\
\text { - the value of total banking assets }\end{array}$ \\
\hline L & Liquidity & $\begin{array}{l}\text { Liquidity points out the ability to cover current liabilities, because failure } \\
\text { to meet obligations when they are due causes mistrust in both clients and } \\
\text { credit institutions, which may then lead to bankruptcy. This is a key source } \\
\text { of systemic risk. } \\
\text { - Liquid Assets Ratio }\end{array}$ \\
\hline S & Sensitivity & $\begin{array}{l}\text { Sensitivity to the market shows whether movements in exchanges rates and } \\
\text { interest rates can be ignored. Unfortunately it does not present correlative } \\
\text { effects in balance sheet items, but indicates potential loss from changes in } \\
\text { exchange rates and evaluates the foreign exchange risk faced by the banking } \\
\text { sector: } \\
\text { - Net Open Position in Foreign Exchange to Capital. }\end{array}$ \\
\hline
\end{tabular}

Source: own compilation.

The construction of the vertexes is not coincidental. The better the result of each ratio, the greater the distance from the centre of the pentagon, so, consequently, the

size of the pentagon is an increasing indication of a better situation in the banking market. The size of the BSP is calculated the using of the following formula:

$$
\begin{gathered}
{\left[\left(C A R \times \frac{N P L}{\text { Total Loans }}\right)+\left(\frac{N P L}{\text { Total Loans }} \times R O A\right)+(\text { ROA } \times \text { Liquidity Ratio })\right.} \\
+(\text { Liquidity Ratio } \times \text { Sensitivity to Market Risk }) \\
+(\text { Sensitivity to Market Risk } \times C A R)] \times k
\end{gathered}
$$

where $k=1 / 2 \sin 72^{\circ}$

The application of the respective indicators is not coincidental, because the bigger the size of pentagon, the more stable the banking sector's situation is. The pentagon's size is equal to the sum of its five triangles and cannot exceed 1; this represents the ideal situation, but one that cannot, unfortunately, be achieved. Therefore, the optimum values for each of the vertexes should be as follows:

a) capital adequacy - between $8 \%$ and $30 \%$

b) share of non-performing loans as part of total loans - between $0 \%$ and $25 \%$; 
c) profitability of assets - between $-7 \%$ and $2 \%$

d) liquidity ratio - between $0 \%$ and $50 \%$;

e) sensitivity to the market risk - between $0 \%$ and $+/-50 \%$.

The rest of the study focuses on the interdependence of the ratios in order to show their role in the process of managing the banking market as a whole. In order to deliver this analysis, the Kolmogorov-Smirnov test was employed to check whether the distributions of the separate variables do not differ significantly over the 2010-2016 study period. If the variables differ significantly from the normal distribution, their correlation will be verified based on the correlation coefficient rho-Spearman and using nonparametric tests. In other cases the r-Pearson correlation coefficient will be calculated. The strength of the relationship is also measured.

\section{The countries studied - characteristics}

In the study, the first region, the Western Balkans, is represented by Bosnia and Hercegovina and Macedonia; while the second region, the Baltic Sea states, is represented by Latvia and Lithuania. All these countries have experienced a common political and economic history. During their periods of non-market economic systems, these countries were members of other huge economies, which also influenced other states.

The countries in the study can be described as not only having a common history in these terms but also common future developments, related with the European Union. The Baltic Sea states have been EU members since 2004, and have recently become euro zone members (Latvia in 2014, and Lithuania in 2015). As a consequence of the deepening of the EU integration process, these countries have been largely dependent on the European Central Bank's (ECB) policy. Lithuania and Latvia joined the euro zone when the EBC decided to focus its policies on banking sector stability and not price stability. Therefore interest rates have been reduced and the ECB continues to buy euro zone bonds.

In 2014, the ECB's actions were concentrated on creating conditions to enable a recovery from the economic stagnation and to improve the monetary transmission process available to enterprises and households.
The Western Balkan countries, instead, have been on the path to the EU accession now. Macedonia earned the status of a candidate state in 2006, while Bosnia submitted its application to join the EU in February 2016. To obtain EU financial aid, both were obliged to adjust their systems of law, including banking law, to meet the Community requirements. By 2013, the Central Bank of Macedonia had introduced a procedure for determining the banking stability index and developed a methodology for identifying systemically important banks. In 2015, the legislation covering the areas of capital adequacy and liquidity risk management were amended; while in 2016 the law was adjusted to reflect the new Basel principles of effective banking supervision and specifying capital buffers (Macedonia Progress Report 2014, 2015, 2016).

The other characteristic that is similar between the countries studied is the structure of their banking sectors. In the past, they operated a relatively similar number of credit institutions (in Latvia and Bosnia around 30 banks, in Macedonia and Lithuania, 15 banks). These banking markets are highly concentrated; for example, in Latvia and Macedonia, CR5 reached over $72 \%$ in 2015, while in Lithuania it was $98 \%$. Only in Bosnia did CR5 remain at a level below $60 \%$. The foreign capital penetration is also high, with the source being the only difference. In the case of the Baltic Sea states, the investors come from Scandinavia, while in the Western Balkans the financial institutions have their roots in Italy, Austria, and Germany. This is the heritage of previous economic relationships dating back as far as 1970s: the former Yugoslavian republic had willingly cooperated with neighbouring countries such as Austria and Italy (Jovanovic, 1972, p. 587). Such a strong dependence on foreign investors resulted in the spill-over of the financial global crisis, which reached the Western Balkans region through indirect channels (Bartlett and Monastiriotis, 2010; Sen Atlay, 2012). The annual rate of credit growth in these countries dropped significantly. A new wave of turbulences in the region resulted from the 2011 euro zone crisis risk aversion strategy that followed. Great hopes were held for the Vienna II initiative launched in March 2012. Unfortunately, it could only slow the pace of the withdrawal of funds from the region, but 
not prevent it. Within three years (20112014) around $8 \%$ of the region's GDP was transferred to the European headquarters of local banks in external bank funds. The investing banking groups have continued operating in the region but on a smaller scale than before (Sanfey, Milatović and Krešić 2016, p. 36).

This proves that the structures of the banking markets in the countries studied are similar, although the key difference is in the size of the sectors, which is a consequence of a delay in the start of the trans- formation process in the Western Balkans compared to the Baltic Sea states.

\section{Research results}

The banking stability pentagon's size manifests completely different changes occurring between both regions. Between 2010 Q1 and 2016 Q3, the BSP's size in the Western Balkans states under study did not change much; while in the countries of the Baltic Sea states, banking stability, represented by the size of the BSP, revealed significant progress (Figure 2).

Figure 2. Size of banking stability pentagon

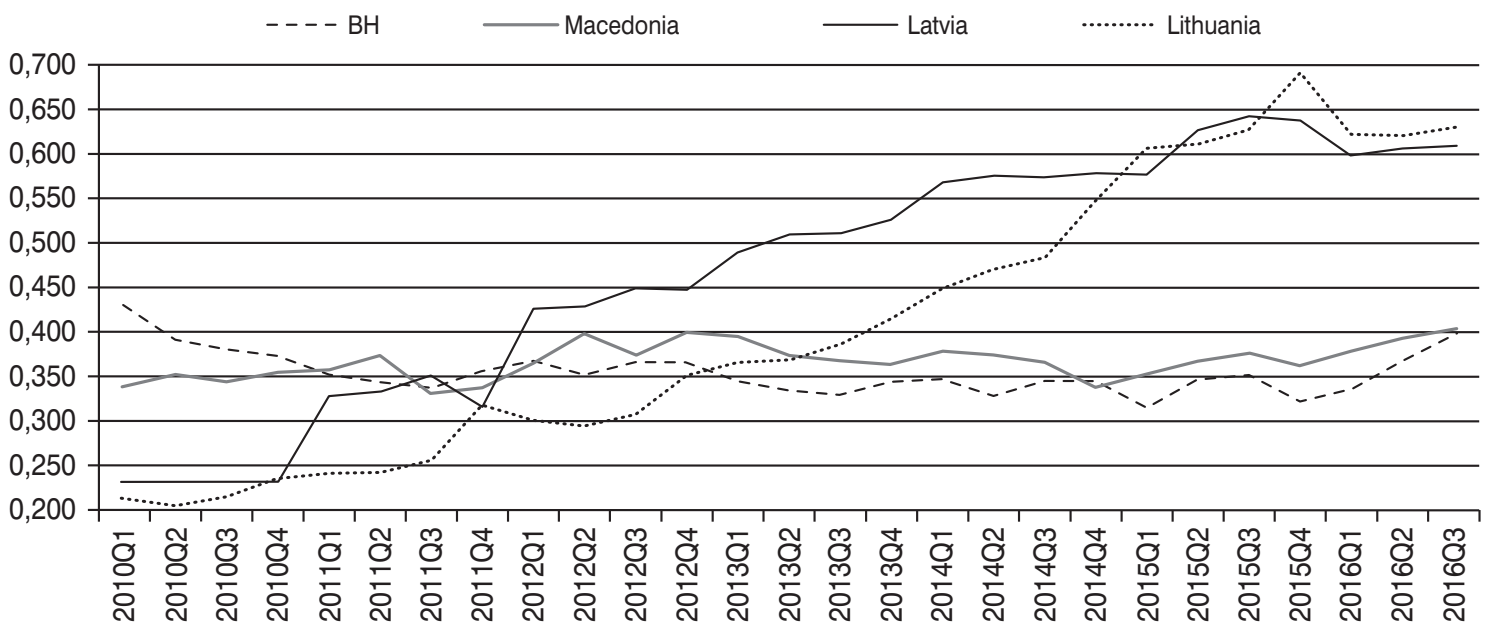

Source: own compilation, based on IMF data

The average rate of stability increase for the Baltic Sea states was similar - between $4.3 \% \mathrm{y} / \mathrm{y}$ in Latvia and $4.5 \% \mathrm{y} / \mathrm{y}$ in Lithuania. This represents an almost tripling in size of the pentagons, proving a more stable situation in the banking sectors. Simultaneously, banking stability in Bosnia decreased, which was manifested in a reduction by 0.032 in the absolute value, and by $7.5 \%$ in the relative value, in the size of its banking stability pentagon. In Macedonia, the situation improved, as indicated by $18 \%$ increase in the pentagon's size over period of study.

The differences in the size of the countries' pentagons at the beginning of 2010 were noticeably large (Figure 3 ). The disparity between the size of pentagons for Bosnia, the biggest, and Lithuania, the smallest, was 2 units. What is important here is that in 2010 the banking stability in the Western Balkan states, manifested in the size of its pentagons, was higher than in the Baltic Sea states. The relatively poor situation in the banking sectors of Lithuania and Latvia resulted from the global economic crisis, which harmed these economies. A research conducted by Maciejewski (2017) on the condition of economies in the European Union in the period 2004-2014 shows that the economic situation in the Baltic Sea States deteriorated significantly in the period immediately after the subprime crisis. The years 2008-2009 brought a visible drop in the rate of economic growth. In 2009, in both Baltic Sea States a negative GDP growth was recorded, however in Latvia it reached the lowest value in the European Union - 18\% y/y (Malina and Mierzwa, 2012). The decreasing production level in 2008 was accompanied by a less efficient use of production factors involved in the production process, thus contributing to a less effective use of the labour factor in the economy and, consequently, to an increase in the unemployment rate. The unemployment rate in both Baltic States reached the level much above 
15\%, growing twice in 2008-2009. (Malina and Mierzwa, 2012; Druzhinin and Prokopyev, 2018). It should also be remembered that the financial and economic crisis has contributed to an increase in the budget deficit and the creation of dangerous public debt which increased twice in this region (Redo, 2016).

\section{Figure 3. Size of banking stability pentagon}

$$
\text { 2010Q1 }
$$

$$
\text { - - - } \mathrm{BH} \longrightarrow \text { Macedonia }
$$

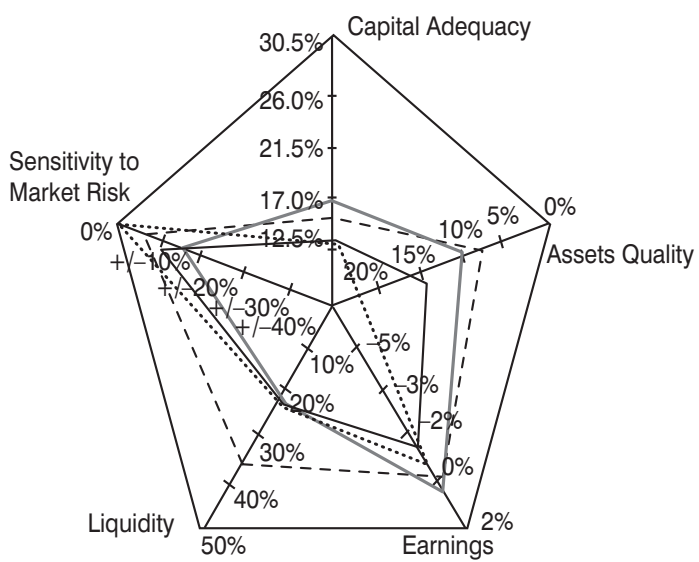

Source: own compilation, based on IMF data.

The situation in 2016 Q3 changed significantly in the countries studied. The sizes of the banking pentagons for Lithuania and Latvia increased much more rapidly than they did for the Western Balkan states, proving that they benefited from the recovery actions that were undertaken. The difference between Bosnia's smallest pentagon and Lithuania's largest was
As these negative changes in relation to the economy as a whole are also treated as determinants of the situation in the banking system, the stability of this system in the first period after subprime crisis in the Baltic countries remained low, also compared to Western Balkan States.

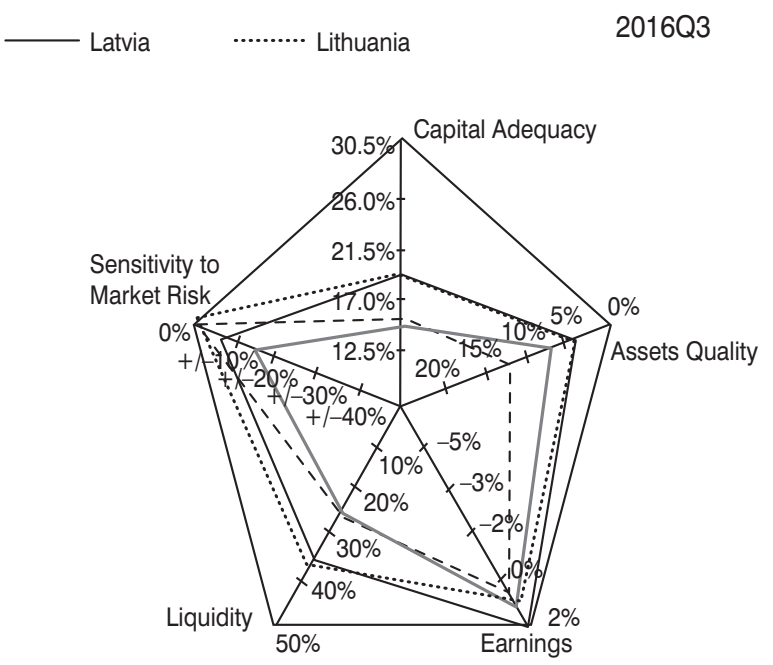

almost $60 \%$. The Baltic Sea states' pentagons achieved a greater average size compared to those of the Western Balkan states. Simultaneously, because Lithuania and Latvia improved their banking stability to a much greater extent, the disparity in the sizes of the pentagons during the period of research was also much bigger (Table 2).

Table 2. Indicators of statistical dispersion - transformation hexagon sizes

\begin{tabular}{|l|c|c|c|c|c|c|c|}
\hline & Min. & Max & Range & Average & SD & SD $^{2}$ & $\begin{array}{c}\text { Coefficient } \\
\text { of variation }\end{array}$ \\
\hline BH & 0.3157 & 0.4294 & 0.3544 & 0.1137 & 0.0248 & 0.0006 & 0.0701 \\
\hline Macedonia & 0.3306 & 0.4035 & 0.3672 & 0.0729 & 0.0200 & 0.0004 & 0.0543 \\
\hline Latvia & 0.2318 & 0.6429 & 0.4682 & 0.4110 & 0.1396 & 0.0195 & 0.2982 \\
\hline Lithuania & 0.2054 & 0.6906 & 0.4101 & 0.4852 & 0.1586 & 0.0252 & 0.3867 \\
\hline
\end{tabular}

Source: own compilation, based on IMF data

The changes in the banking stability pentagons are a consequence of various tendencies of each individual ratio describing each banking sector (Figure 4 and Table 3 ). For the countries studied, completely different changes are recorded in the area of capital adequacy. In all countries, the CAR ratio exceeded $13 \%$ of risk-weighted assets, but prior to 2013 Q2 capital adequacy was higher in the Western Balkans, while later on the Baltic Sea states overlapped in this area, ending the research period with a CAR level of close to $20 \%$ of riskweighted assets. Due to the completely dif- 

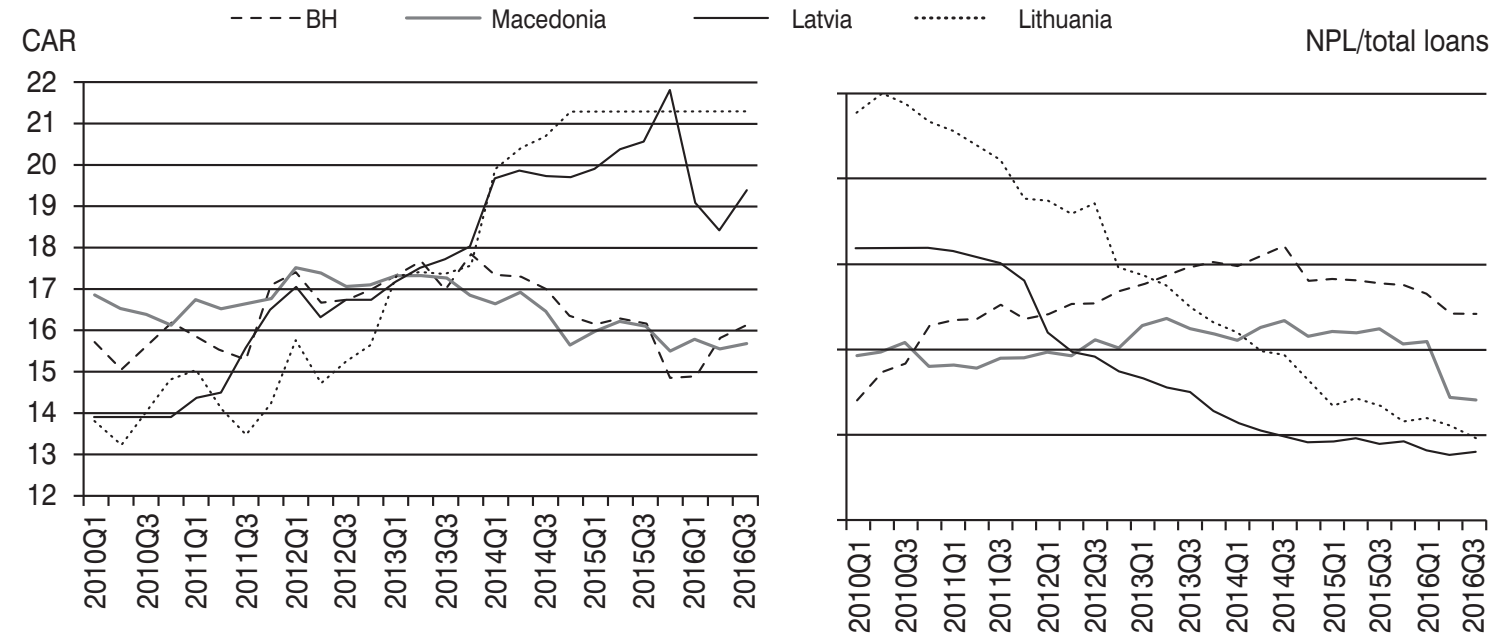

ROA

Liquidity Ratio
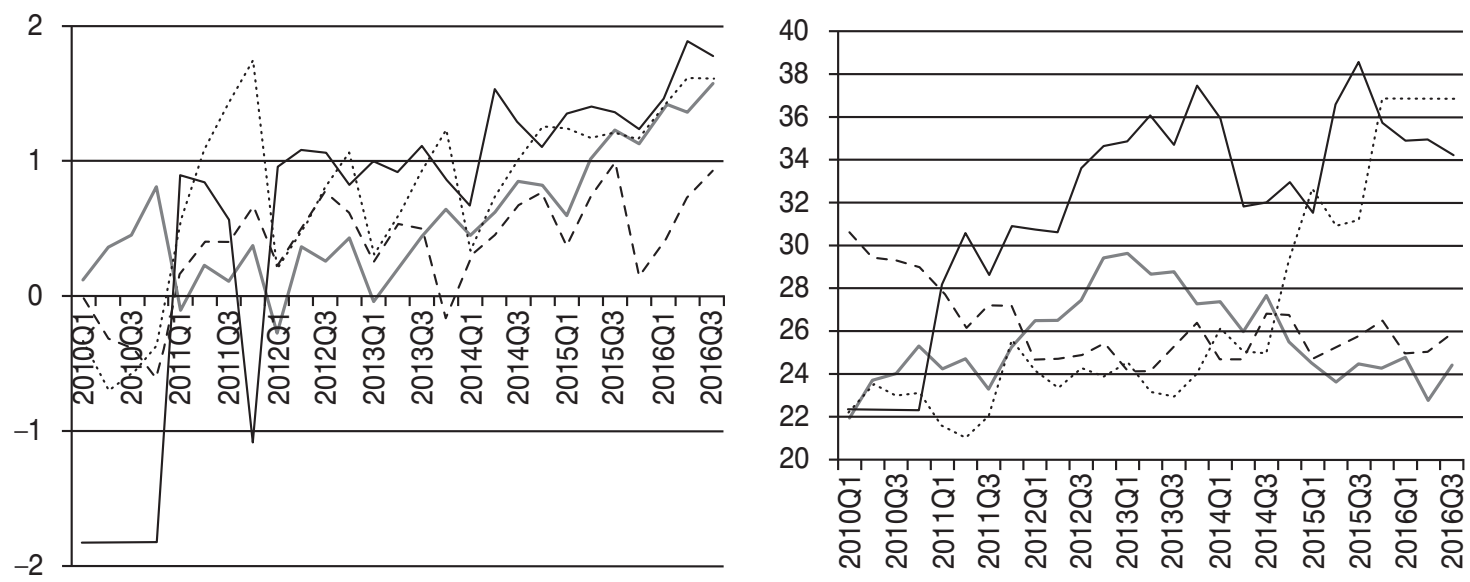

Net Open Position in Foreign Exchange to Capital

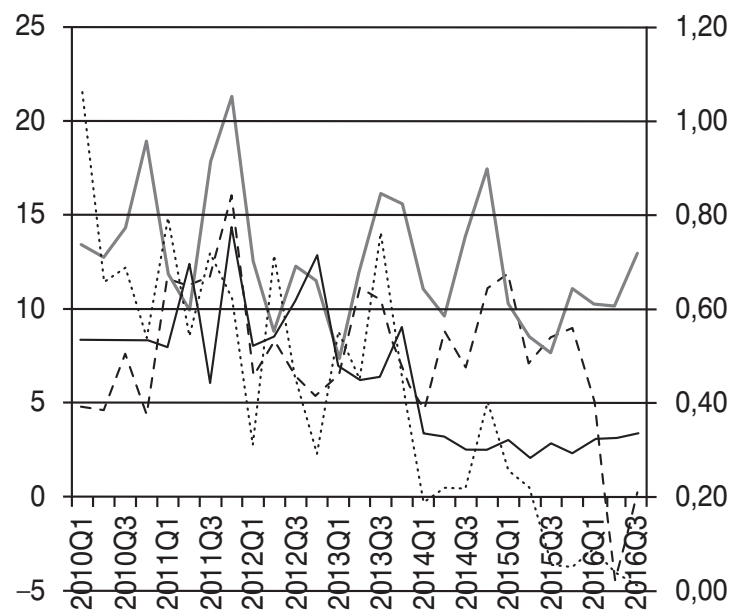

Source: own compilation, based on IMF data.

ferent changes in the CAR, the dispersion of the ratio was much higher in Lithuania and Latvia than in the other countries.

The quality of assets measured using the share of non-performing loans as

a part of total loans, changed the situation dramatically. In the Baltic Sea states the ratio dropped from the 2010 levels of $15 \%$ in Latvia and close to $25 \%$ in Lithuania, to close to $5 \%$ in 2016 Q3. This was the 


\begin{tabular}{|c|c|c|c|c|c|c|c|}
\hline & Min. & Max & Range & Average & SD & $\mathrm{SD}^{2}$ & $\begin{array}{c}\text { Coefficient } \\
\text { of variation }\end{array}$ \\
\hline \multicolumn{8}{|c|}{ Regulatory Capital as part of Risk-Weighted Assets } \\
\hline BH & 14.86 & 17.83 & 2.97 & 16.38 & 0.86 & 0.74 & 0.05 \\
\hline Macedonia & 15.49 & 17.50 & 2.01 & 16.56 & 0.60 & 0.36 & 0.04 \\
\hline Latvia & 13.91 & 21.82 & 7.91 & 17.50 & 2.38 & 5.67 & 0.14 \\
\hline Lithuania & 13.24 & 21.29 & 8.05 & 17.59 & 3.13 & 9.78 & 0.18 \\
\hline \multicolumn{8}{|c|}{ Non-performing Loans as part of Total Gross Loans } \\
\hline BH & 7.12 & 16.08 & 8.96 & 12.85 & 2.07 & 4.29 & 0.16 \\
\hline Macedonia & 7.07 & 11.81 & 4.74 & 10.16 & 1.19 & 1.43 & 0.12 \\
\hline Latvia & 3.85 & 15.93 & 12.09 & 9.05 & 4.68 & 21.95 & 0.52 \\
\hline Lithuania & 4.87 & 25.01 & 20.14 & 14.26 & 6.83 & 46.67 & 0.48 \\
\hline \multicolumn{8}{|c|}{ Return On Assets } \\
\hline BH & -0.61 & 0.98 & 1.59 & 0.37 & 0.40 & 0.16 & 1.07 \\
\hline Macedonia & -0.28 & 1.57 & 1.84 & 0.57 & 0.48 & 0.23 & 0.84 \\
\hline Latvia & -1.82 & 1.89 & 3.71 & 0.62 & 1.16 & 1.36 & 1.87 \\
\hline Lithuania & -0.70 & 1.75 & 2.45 & 0.78 & 0.68 & 0.46 & 0.87 \\
\hline \multicolumn{8}{|c|}{ Liquid Assets as part of Total Assets (Liquid Asset Ratio) } \\
\hline BH & 24.12 & 30.57 & 6.45 & 26.20 & 1.75 & 3.06 & 0.07 \\
\hline Macedonia & 22.01 & 29.62 & 7.61 & 25.63 & 2.07 & 4.28 & 0.08 \\
\hline Latvia & 22.34 & 38.56 & 16.22 & 31.85 & 4.78 & 22.86 & 0.15 \\
\hline Lithuania & 21.04 & 36.86 & 15.82 & 26.67 & 5.21 & 27.15 & 0.20 \\
\hline \multicolumn{8}{|c|}{ Net Open Position in Foreign Exchange as a part of Capital } \\
\hline BH & -4.50 & 15.99 & 20.49 & 7.46 & 4.06 & 16.47 & 0.54 \\
\hline Macedonia & 7.34 & 21.33 & 13.99 & 12.58 & 3.50 & 12.25 & 0.28 \\
\hline Latvia & 2.07 & 14.33 & 12.27 & 6.45 & 3.55 & 12.62 & 0.55 \\
\hline Lithuania & 0.01 & 1.06 & 1.04 & 0.42 & 0.28 & 0.08 & 0.66 \\
\hline
\end{tabular}

Source: own compilation, based on IMF data.

effect of an improving general situation in the region. At the same time, the ratio in question in Bosnia and Macedonia kept increasing until mid-2015 and then began to decrease, but not to such a low level as in the other region. In this case, the dispersion of the quality assets ratio was much higher in the Baltic Sea states.

In the case of profitability, the biggest improvement was achieved by Latvia, where the return on assets increased from $-1.82 \%$ to over $1.87 \%$. In 2010 , only Macedonia did not experience negative profitability in the banking sector. The countries recorded growing profitability, although, still, the Baltic Sea states noted higher dispersions, but these were much less significant compared to the other indices. Profitability in the Baltic states was higher than in the Balkan countries, which could have been achieved thanks to the higher diversity of income measured by the share of interest margin as part of gross income, and non-interest expenses as part of the gross income, which was lower in the Baltic states.

Considering the banking sectors' liquidity, there are noticeable, opposite trends in the countries studied. They began the researched period with lower liquidity, at 
a level of $22 \%$ of total assets. The Baltic Sea states ended 2016 Q3 with a liquidity level between $34 \%$ and $37 \%$, while in the Western Balkans it was not more than $26 \%$ of total assets. The consequence of these changes is a higher dispersion of the liquidity ratio in Lithuania and Latvia. This can be explained by the fact that the consequences of the global financial crisis had a more serious effect in the Baltic Sea States than in the Western Balkans

The last, but not least important area of study is the sensitivity to market risk, measured using the share of net open position in foreign exchange as a part of capital. The ratio was definitely higher in countries from south-eastern Europe than in the Baltic Sea states, especially in Macedonia where the ratio did not fall below $7 \%$, and which is relatively underdeveloped as far as its banking sector is considered. Generally, the countries normally ended the booking year with the long position, but in 2016 Q2 Bosnia recorded a short position at a level of $-4.5 \%$

Summing that up, it should be emphasised that the Baltic Sea states achieved greater progress and improvement, which is presented both in a higher average value of the ratios and much higher dispersions in the comparative analysis.

\section{The interdependence of ratios in banking markets}

In order to choose the appropriate statistical test, we will check whether the distributions of the separate variables in the period of 2010-2016 do not differ significantly from the normal distribution. The results are presented in Table 4.

Table 4. The results of Kolmogorov-Smirnov test

\begin{tabular}{|l|l|r|r|r|r|r|}
\hline \multirow{4}{*}{ BH } & Variable & CAR & NPL & ROA & Liquid Ratio & $\begin{array}{c}\text { Net Open } \\
\text { Position }\end{array}$ \\
\hline \multirow{4}{*}{ Macedonia } & Average & 16.374 & 12.856 & 0.37 & 26.211 & 7.47 \\
\cline { 2 - 7 } & KS & 0.139 & 0.141 & 0.159 & 0.159 & 0.151 \\
\cline { 2 - 7 } & value p & 0.626 & 0.61 & 0.455 & 0.454 & 0.524 \\
\cline { 2 - 7 } & Average & 16.559 & 10.159 & 0.57 & 25.641 & 12.578 \\
\cline { 2 - 7 } & KS & 0.112 & 0.104 & 0.157 & 0.139 & 0.13 \\
\hline \multirow{3}{*}{ Latvia } & value p & 0.85 & 0.901 & 0.472 & 0.624 & 0.704 \\
\cline { 2 - 7 } & KS & 17.496 & 9.044 & 0.63 & 31.837 & 6.441 \\
\cline { 2 - 7 } & value p & 0.12 & 0.17 & 0.205 & 0.176 & 0.211 \\
\hline \multirow{3}{*}{ Lithuania } & Average & 17.778 & 14.267 & 0.781 & 25.304 & 0.419 \\
\cline { 2 - 7 } & KS & 0.156 & 0.115 & 0.162 & 0.215 & 0.119 \\
\cline { 2 - 7 } & value p & 0.483 & 0.829 & 0.432 & 0.143 & 0.797 \\
\hline
\end{tabular}

* p - value statistically significant

Source: own compilation, based on IMF data.

Only in Latvia did the statistical tests show that the distribution of return on assets differed significantly from the normal distribution, so the correlation of this variable will be verified based on the rhoSpearman correlation coefficient and using nonparametric tests. In contrast, in both Balkan countries as well as in Lithuania the statistical tests conducted (KolmogorovSmirnov test) did not show that the dis- tributions of the individual ratios differed significantly from the normal distribution; thus the variables do not differ significantly from the norm. Therefore, to examine the relationship between all of the variables, an r-Pearson correlation coefficient was calculated and the results for Bosnia and Hercegovina and Macedonia are presented in Table 5. 
Table 5. Results of the correlation coefficient for Bosnia and Hercegovina and Macedonia

\begin{tabular}{|c|c|c|c|c|c|c|c|c|}
\hline & \multicolumn{4}{|c|}{ Bosnia \& Hercegovina } & \multicolumn{4}{|c|}{ Macedonia } \\
\hline & CAR & NPL & ROA & $\begin{array}{c}\text { Liquid } \\
\text { Ratio }\end{array}$ & CAR & NPL & ROA & $\begin{array}{l}\text { Liquid } \\
\text { Ratio }\end{array}$ \\
\hline $\begin{array}{l}\text { NPL } \\
\mathrm{r} \\
\text { test T } \\
\mathrm{p} \text { - value }\end{array}$ & $\begin{array}{l}0.537 \\
3.186 \\
0.004\end{array}$ & & & & $\begin{array}{l}0.341 \\
1.812 \\
0.082\end{array}$ & & & \\
\hline $\begin{array}{l}\text { ROA } \\
\mathrm{r} \\
\text { test T } \\
\mathrm{p}-\text { value }\end{array}$ & $\begin{array}{c}0.191 \\
0.973 \\
0.34\end{array}$ & $\begin{array}{c}0.459 \\
2.583 \\
0.016^{*}\end{array}$ & & & $\begin{array}{l}-0.809 \\
-6.889 \\
<0.001\end{array}$ & $\begin{array}{c}-0.227 \\
-1.164 \\
0.255\end{array}$ & & \\
\hline $\begin{array}{l}\text { Liquid Ratio } \\
\mathrm{r} \\
\text { test } \mathrm{T} \\
\mathrm{p}-\text { value }\end{array}$ & $\begin{array}{c}-0.488 \\
-2.794 \\
0.01^{*}\end{array}$ & $\begin{array}{c}-738 \\
-5.474 \\
<0.001 *\end{array}$ & $\begin{array}{l}-0.583 \\
-3.592 \\
0.001^{*}\end{array}$ & & $\begin{array}{c}0.611 \\
3.857 \\
0.001 *\end{array}$ & $\begin{array}{c}0.518 \\
3.03 \\
0.006^{*}\end{array}$ & $\begin{array}{c}-0.296 \\
-1.551 \\
0.133\end{array}$ & \\
\hline $\begin{array}{l}\text { NetOpenPos. } \\
\mathrm{r} \\
\text { test } \mathrm{T} \\
\mathrm{p}-\text { value }\end{array}$ & $\begin{array}{l}0.127 \\
0.643 \\
0.526\end{array}$ & $\begin{array}{l}0.192 \\
0.977 \\
0.338\end{array}$ & $\begin{array}{l}0.064 \\
0.323 \\
0.749\end{array}$ & $\begin{array}{l}0.011 \\
0.055 \\
0.957\end{array}$ & $\begin{array}{c}-0.006 \\
-0.032 \\
0.975\end{array}$ & $\begin{array}{c}-0.148 \\
-0.75 \\
0.461\end{array}$ & $\begin{array}{r}-0.126 \\
-0.634 \\
0 . .532\end{array}$ & $\begin{array}{c}-0.051 \\
-0.254 \\
0.802\end{array}$ \\
\hline
\end{tabular}

$\mathrm{r}$ - correlation ratio of $\mathrm{r}$-Pearsona; test $\mathrm{T}$ - test $\mathrm{T}$ of the correlation ratio; * $\mathrm{p}$-value statistically significant

Source: own compilation, based on IMF data.

The statistical tests performed for the correlation coefficient ( $p$-value $<0.05$ ) for Bosnia confirmed that there is a statistically significant, positive correlation between the quality of assets, capital adequacy and profitability, meaning that, with an increase in the assets quality measured using a decreasing share of NPL as part of total loans, the other variables should also increase, and the correlation between them is moderate.

The other finding is that there is a negative correlation between liquidity and capital adequacy, as well as between the quality of assets and profitability, but the strength of the relationships varies; while there is a moderate strength relationship between liquidity and capital adequacy, between liquidity and the other two variables, the strength is high.

In the case of Macedonia, the findings are very different. Only a moderate positive correlation is confirmed between liquidity and quality of assets, while there is a strong positive relationship between liquidity and capital adequacy. The other finding is a strong negative correlation between capital adequacy and profitability.
For the other pairs of variables, at the level of statistical significance, the tests have not confirmed the existence of statistically significant relationships. The results of the confirmed tests show that the banking sectors under study develop in different ways. Secondly, other instruments are needed to improve general situation in the sectors. Both issues are worth of further study.

The next analysis is conducted for Latvia and Lithuania. The results are presented in Table 6.

In the case of Latvia and Lithuania, the statistical tests performed for the correlation coefficient ( $p$-value $<0.05$ ) confirmed that there are much more statistically significant correlations. Firstly, both countries reveal a strong positive correlation between capital adequacy and liquidity.

Such a correlation is also confirmed in Latvia between capital adequacy and profitability, as well as between quality of assets and sensitivity to market risk; while in Lithuania it occurs between quality of assets and sensitivity to market risk.

A moderate positive relationship was found in Latvia between liquidity and 


\begin{tabular}{|c|c|c|c|c|c|c|c|c|}
\hline & \multicolumn{4}{|c|}{ Latvia } & \multicolumn{4}{|c|}{ Lithuania } \\
\hline & CAR & NPL & ROA & $\begin{array}{l}\text { Liquid } \\
\text { Ratio }\end{array}$ & CAR & NPL & ROA & $\begin{array}{c}\text { Liquid } \\
\text { Ratio }\end{array}$ \\
\hline $\begin{array}{l}\text { NPL } \\
\mathrm{r} \\
\text { test T } \\
\mathrm{p}-\text { value }\end{array}$ & $\begin{array}{c}-938 \\
-13.516 \\
<0.001 *\end{array}$ & & & & $\begin{array}{c}-0.901 \\
-10.4 \\
<0.001 *\end{array}$ & & & \\
\hline $\begin{array}{l}\text { ROA } \\
\text { r / rho } \\
\text { test T } \\
\text { p - value }\end{array}$ & $\begin{array}{c}0.79 \\
6.443 \\
<0.001 *\end{array}$ & $\begin{array}{c}-878 \\
-9.152 \\
<0.001 *\end{array}$ & & & $\begin{array}{c}0.479 \\
2.731 \\
0.011^{*}\end{array}$ & $\begin{array}{l}-0.676 \\
-4.581 \\
<0.001\end{array}$ & & \\
\hline $\begin{array}{l}\text { Liquid } \\
\text { Ratio } \\
\text { r / rho } \\
\text { test T } \\
\text { p - value }\end{array}$ & $\begin{array}{c}0.791 \\
6.471 \\
<0.001 *\end{array}$ & $\begin{array}{l}-0.819 \\
-7.127 \\
<0.001^{*}\end{array}$ & $\begin{array}{c}0.548 \\
3.274 \\
0.003 *\end{array}$ & & $\begin{array}{c}0.842 \\
7.799 \\
<0.001 *\end{array}$ & $\begin{array}{c}-0.861 \\
-8.495 \\
<0.001 *\end{array}$ & $\begin{array}{c}0.537 \\
3.185 \\
0.004^{*}\end{array}$ & \\
\hline $\begin{array}{l}\text { NOP } \\
\text { r / rho } \\
\text { test T } \\
\mathrm{p}-\text { value }\end{array}$ & $\begin{array}{c}-0.738 \\
-5464 \\
<0.001 *\end{array}$ & $\begin{array}{c}0.716 \\
5.127 \\
<0.001 *\end{array}$ & $\begin{array}{c}-0.67 \\
-4.512 \\
<0.001\end{array}$ & $\begin{array}{c}-0.362 \\
-1.939 \\
0.064\end{array}$ & $\begin{array}{l}-0.737 \\
-5.447 \\
<0.001\end{array}$ & $\begin{array}{c}-0.808 \\
6.857 \\
<0.001^{*}\end{array}$ & $\begin{array}{l}-0.538 \\
-3.192 \\
0.004^{*}\end{array}$ & $\begin{array}{l}-0.758 \\
-5.804 \\
<0.001 *\end{array}$ \\
\hline
\end{tabular}

$\mathrm{r}$ - correlation ratio of $\mathrm{r}$-Pearsona; test $\mathrm{T}-$ test $\mathrm{T}$ of the correlation ratio; ${ }^{*} \mathrm{p}$ - value statistically significant

Source: own compilation, based on IMF data.

profitability, while in Lithuania there was a relationship between profitability, capital adequacy and liquidity.

Secondly, the tests performed for both countries proved a strong negative correlation existed between the quality of assets and capital adequacy, liquidity and profitability, as well as between sensitivity to market risk and capital adequacy.

A moderate, negative relationship was found between sensitivity to market risk and profitability in Latvia, but with liquidity in Lithuania. For other pairs of variables at the level of statistical significance, statistical tests carried out did not confirm the existence of statistically significant relationships.

\section{Conclusions}

As revealed by the analysis carried out, the size of the banking stability pentagon indicates completely different changes occurring in both regions within the scope of stability. Between 2010 Q1 and 2016 Q3 BSP sizes in the Western Balkan region states taken into account did not change much; while the increase in the size of the BSPs for the countries from the Baltic Sea states was significant. All of the banking sectors studied experienced negative effects caused by the global financial crisis but the current transforming process turns out to be an aggravating factor in the recovery situation.

The test confirmed the existence of some correlations between the individual ratios in the countries studied between 2010 Q1 and 2016 Q3, but unfortunately they depend on the region analysed. Most of the results of the tests proved that the relationships between various variables have similar directions and strengths in Lithuania and Latvia. Most correlations in these countries are described as strong positive or strong negative. Only in two cases were the correlations confirmed in both the Baltic Sea states and one of the Western Balkan countries: namely, in Macedonia - the strong positive relationship between capital adequacy and quality of assets, and in Bosnia and Hercegovina - the strong negative correlation between liquidity and quality of assets. Unfortunately, there wasn't a correlation confirmed, either identical or similar, between variables in the in 
the Western Balkans countries, which may be explained as by various ways in which the banking sectors perform there.

\section{References}

Abusharba, M.T., Triyuwono, I., Ismail, M. and Rahman, A.F. (2013). Determinants of Capital Adequacy Ratio (CAR) in Indonesian Islamic Commercial Banks. Global Review of Accounting and Finance, 4(1).

Acharya, V. (2009). A Theory of Systemic Risk and Design of Prudential Bank Regulation. Journal of Financial Stability, https://doi.org/10.2139/ ssrn.236401

Acharya, V.V. and Naqvi, H., (2012) The seeds of a crisis: a theory of bank-liquidity and risk-taking over the business cycle. Journal of Financial Economics, 106, https://doi.org/10.2469/dig.v43.n1.25

Ahmad, R., Ariff, A. and Michael, J.S. (2008), The Determinants of Bank capital ratios in a developing economy. CARF Working paper, March, Asia - Pacific Financial Markets, 15 (3-4), https://doi. org/10.1007/s10690-009-9081-9

Albulescu, C. (2010) Forecasting the Romanian Financial Sector Stability Using a Stochastic Simulation Model. Romanian Journal of Economic Forecasting, 1 .

Athanasoglou, P.P., Brissimis, S.N. and Delis, M.D. (2007). Bank specific, industry specific and macroeconomic determinants of bank profitability. Journal of International Financial Markets, Institutions and Money, 18(2).

Babihuga, R. (2007) Macroeconomic and Financial Soundness Indicators: An Empirical Investigation. IMF Working Paper, 07/115, https://doi. org/10.5089/9781451866797.001

Bartlett, W. and Monastiriotis, V. (2010). South East Europe after the economic crisis: a new dawn or back to business as usual? London School of Economics and Political Science: LSE European Institute.

Bordo, M.D., Eichengreen, B., Klingebiel, D. and Martinez-Peria, M.S. (2001). Is the Crisis Problem Growing More Severe? Economic Policy.

Brownbridge, M., Gockel, A.F. and Harrington, R. (2000). Savings and Investment. In: E. Aryeetey, J. Harrigan and M. Nissanke (eds.), Economic Reforms in Ghana: The Reality and Mirage. London: James Currey.

Bryant, J. (1980). A model of reserves, bank runs and deposit insurance. Journal of Banking \& Finance, 4, https://doi.org/10.1016/03784266(80)90012-6

Büyüksalvarc, A. and Abdioğlu, H. (2011). Determinants of capital adequacy ratio in Turkish Banks: A panel data analysis. African Journal of Busi- ness Management, 5(27), https://doi.org/10.5897/ ajbm11.1957

Cai, J. and Thakor, A.V. (2008). Liquidity Risk, Credit Risk, and Interbank Competition. Working Paper, https://doi.org/10.2139/ssrn.1103548

Cheang, N. and Choy, I. (2011). Aggregate Financial Stability Index for an Early Warning System, Monetary Authority of Macao. Macao Monetary Research Bulletin, 21.

Cihák, M. and Schaeck, K. (2007). How Well Do Aggregate Bank Ratios Identify Banking Problems?, IMF Working Papers, 1-40, https://doi. org/10.5089/9781451868388.001

Čihák, M. and Schaeck K. (2010). How Well do Aggregate Prudential Ratios Identify Banking System Problem? Journal of Financial Stability, 6(3), https://doi.org/10.5089/9781451868388.001

Claessens, S., Dermiguc Kunt, A. and Huizinga, H. (2001) How does foreign banking entry affect domestic banking markets? Journal of Banking and Finance, 25(5), doi:10.1016/S0378-4266(00)00102-3

Demirgüç-Kunt, A. and Huizinga H., (1999) Determinants of Commercial Bank Interest Margins and Profitability: Some International Evidence. World Bank Economic Review, 13(2), https://doi. org/10.1093/wber/13.2.379

Diamond, D.W. and Dybvig, P.H. (1983) Bank runs, deposit insurance, and liquidity. The Journal of Political Economy, 91, https://doi.org/10.1086/261155

Dietrich, A. and Wanzenried, G. (2011). Determinants of Bank Profitability before and during the Crisis: Evidence from Switzerland. Journal of International Financial Markets, Institutions and Money, 21(3), https://doi.org/10.2139/ssrn.1370245

Druzhinin, P.V. and Prokopyev, E.A. (2018). An Assessment of the Economic Performance of the EU Baltic Region States. Baltic Region, 10(1), 4-18, https://doi.org/10.5922/ 2079-8555-2018-1-1

Feldman, R.A. and Wagner, N. (2002). The financial sector, macroeconomic policy and performance, EIB Papers, 7(2).

Fu, X. and Heffernan, S.A. (2008). The Effects of Reform on China's Bank Structure and Performance. Journal of Banking and Finance, https://doi. org/10.2139/ssrn.903347

Gatev, E., Schuermann, T. and Strahan, P.E. (2009) Managing bank liquidity risk: how deposit-loan synergies vary with market conditions. Review of Financial Studies, 22, https://doi.org/10.3386/w12234

Geršl, A. and Hermanek, J. (2008). Indicators of financial system stability: towards an aggregate financial stability indicator? Prague Economic Papers, 17(2), https://doi.org/ 10.18267/j.pep.325

Gropp, R. and Vesala, J. (2001) Deposit Insurance and Moral Hazard: Does the Counterfactual Matter? Working Paper, European Central Bank. 
Guru, B.K., Staunton, J. and Balashanmugam, B. (2002) Determinants of Commercial Bank Profitability in Malaysia. Working Paper. Multimedia University.

Hanschel, E. and Monnin, P. (2005). Measuring and Forecasting Stress in the Banking Sector: Evidence from Switzerland. BIS Papers No. 22: Investigating the Relationship Between the Financial and Real Economy, 431-49. Bank for International Settlements.

Illing, M. and Liu, Y. (2006). Measuring Financial Stress in a Developed Country: An Application to Canada. Journal of Financial Stability, 2(3).

Imbierowicz, R. (2014). The relationship between liquidity risk and credit risk in banks. Journal of Banking \& Finance, 40

Iyer, R. and Puri, M. (2012). Understanding bank runs: the importance of depositor-bank relationships and networks. American Economic Review, 102 .

Jovanovic, M. (1972). Yugoslav Trade With EEC And Comecon Countries. Law and Contemporary Problems, 586-591, https://doi.org/10.2307/1191142

Khan, S.R. and Aftab, S. (1994). Assessing the Impact of Financial Reforms on Pakistan's Economy. Pakistan Journal of Applied Economics, 10.

Kleff, V. and Weber, M. (2008). How Do Banks Determine Capital? Empirical Evidence from Germany. Germain Economic Review, 9(3).

Košak, M. and Čok, M. (2008). Ownership structure and profitability of the banking sector: The evidence from the SEE region. Zb. rad. Ekon. fak. Rij, 26(1).

Kosmidou, K. (2008). The determinants of banks' profits in Greece during the period of EU financial integration. Managerial Finance, 34(3).

Kundid, A., Škrabić, B. and Ercegovac, R. (2011). Determinants of bank profitability in Croatia, Croatian Operational Research Review, 2.

Maciejewski, M. (2017) Zróżnicowanie kondycji gospodarczej państw Unii Europejskiej, Studia Ekonomiczne. Zeszyty Naukowe Uniwersytetu Ekonomicznego w Katowicach, 319.
Malina, A. and Mierzwa, D. (2012). Analiza porównawcza sytuacji makroekonomicznej Polski i krajów ościennych w okresie 20 lat przemian gospodarczych. Prace Naukowe Uniwersytetu Ekonomicznego we Wroctawiu, 244, 330-341.

Naceur, B.S. and Goaied, M. (2008) The determinants of commercial bank interest margin and profitability: Evidence from Tunisia. Frontiers in Finance and Economics, 5(1), https://doi. org/10.2139/ssrn.856365

Navajas, M.C. and Thegeya, A. (2013). Financial Sound ness Indicators and Banking Crises. International Monetary Fund Working Paper WP/13/263.

Petrovska, M. and Mucheva Mihajlovska, E. (2013). Measures of Financial Stability in Macedonia. Journal of Central Banking Theory and Practice, 2(3), 85-110.

Pervan, M., Pervan, I. and Guadagnino, A. (2010). Market Structure and Profitability of Croatian Commercial Banks. The Business Review, 16(1).

Puddu, S. (2008). Optimal Weights and Stress Banking Indexes. HEC Université de Lausanne.

Progress Reports, 2014, 2015-2016, Macedonia.

Redo, M. (2016). Analiza przemian gospodarczych w krajach Europy Środkowo-Wschodniej należących do Unii Europejskiej w latach 2003-2014. WSB University in Wroclaw Research Journal, 16(2).

Samartín, M. (2003). Should bank runs be prevented? Journal of Banking \& Finance, 27.

Sanfey, P., Milatović, J. and Krešić, A. (2016). How the Western Balkans can catch up. EBRD Working Papers, 36.

Sen, A. and Atlay, H. (2012). The Channels of Contagion in the Global Crisis: The Case of the Southeastern Europe Countries. Journal of Economic and Social Studies, 2(2).

Sun, T. (2011). Identifying Vulnerabilities in Systemically Important Financial Institutions in a Macro-financial Linkages Framework. International Monetary Fund Working Paper 11/11. Washington.

Wagner, W. (2007). The liquidity of bank assets and bank liquidity. Journal of Banking \& Finance, 31. 